УДК 347.73

DOI https://doi.org/10.32837/pyuv.v2i4(29).454

\author{
В. М. Прасюк \\ orcid.org/0000-0002-1681-8662 \\ здобувач кафедри адліністративного та господарського права \\ Запорізького національного університету
}

\title{
ПРИНЦИПИ ДЕРЖАВНОГО ФІНАНСОВОГО КОНТРОЛЮ: ЗАГАЛЬНА ХАРАКТЕРИСТИКА
}

Із метою поєднання надбань юридичної науки і практичного правозастосування вітчизняні науковці дедалі більшу увагу приділяють дослідженню принципів у різних сферах правового життя. Однак, враховуючи важливість внеску вчених у дослідження такого багатогранного питання, як принципи, а також численність наукових розробок тематики принципів у праві, не можна не звернути увагу на те, що у цій сфері результати дослідження є спірними і дотепер залишаються актуальними. Вказана проблема зумовлює необхідність комплексного дослідження принципів також у зв'язку із тим, що вона є основоположною у розвитку всього права. Тому пропонується проведення наукового пошуку й обгрунтування нових теоретичних позицій визначення поняття принципів державного фінансового контролю та 3'ясування їхньої сутності.

Насамперед варто звернутися до аналізу загального поняття принципу, оскільки це твердження сприймається як головне, важливе, суттєве. Принципи - це «основне, найзагальніше, вихідне положення, засіб, правило, яке визначає природу та соціальну сутність явища, його спрямованість і найсуттєвіші властивості» [1, с. 43]. Термін «принцип» походить від латинського слова «principium» і буквально перекладається як «те, з чого все починається» [2] й означає «базові засади, фундаментальну основу, вимоги" тощо. Водночас, за визначенням словника іншомовних слів, принцип - це те, що «знаходиться в основі певної теорії науки, внутрішне переконання людини, основне правило поведінки" [3, с. 547]. Філософський енциклопедичний словник свідчить про те, що принцип є синонімом життєвої позиції, його називають внутрішнім переконанням людини - практичними, моральними й теоретичними засадами, якими вона керується у реальному житті, у різноманітних сферах діяльності. У філософській довідковій літературі під принципами також розуміють загальні вимоги до побудови системи теоретичного знання, сформульовані як те первинне, першопочаткове, що лежить в основі певної сукупності фактів [4, с. 519]. У юридичній літературі в означенні «принципу» застосовуються: першооснова, підстава, аксіома, постулат, передумова знання, керівна ідея, центральне поняття, ланка, яка пов'язує ключове поняття, від- правний пункт пояснення, основоположне теоретичне знання, вираження необхідності або закону явищ, одна з логічних функцій закону, внутрішне переконання людини й погляд на речі [5, с. 12].

Із перелічених словникових визначень термін «принцип» розкривається як основні, вихідні положення певної теорії, вчення, науки, світосприйняття тощо. Проте у дослідженні організації та здійсненні державного фінансового контролю розглянемо принципи як основоположні ідеї, керівні засади, фундаментальні положення, вихідні начала, які є найсуттєвішою основою не лише правових норм, а й усієї правозастосовчої діяльності.

Однією з найважливіших умов досягнення мети та цільових завдань державного фінансового контролю, створення його єдиної й ефективної системи є додержання принципів контролю, тобто головних вимог, правил, стандартів, що охоплюють процедури контрольної діяльності загалом. Принципи державного фінансового контролю розкривають внутрішні закономірності організації та здійснення контролю і водночас зумовлюють суворі вимоги, згідно з якими створюється та функціонує система фінансового контролю у системі публічного адміністрування.

Державний фінансовий контроль здійснюється певними державними органами, а це означає, що виконання завдань кожного з них так або інакше пов'язане із принципами, які виступають основоположним фундаментом їхньої діяльності. Також слід зазначити, що державний фінансовий контроль реалізується за тими ж принципами, що і фінансова діяльність, тому що контроль $є$ її складовою частиною. Між тим, фінансовий контроль має і специфічні принципи, викладені в Лімській декларації керівних принципів контролю. Це зумовлено тим, що в сучасному суспільстві формується єдина система стандартизації державного фінансового контролю, мета якої полягає в розробці загальних принципів діяльності контролюючих органів.

Передусім варто констатувати, що в юридичній літературі немає, по-перше, однозначної дефініції поняття «принципи державного фінансового контролю", адже його визначення залежить від контексту застосування та позиції того чи іншого автора, i, по-друге, відсутня єдина думка щодо переліку принципів державного фінансового 
контролю. Слід зазначити, що питання принципів контролю привертали увагу вчених-адміністративістів як загалом, так і щодо розгляду окремих його різновидів (державного, фінансового тощо). Так, В.М. Гаращук зазначає: «У юридичній науці під принципами контролю слід розуміти розроблені з урахуванням досягнень науки управління і втілені в практику організаційні та правові основи організації та здійснення контролю, що забезпечують його результативність» [6, с. 99]. Вчений акцентує увагу на комплексному характері відповідних принципів, адже вони поєднують у собі ознаки фундаменту, базису контрольної діяльності, правових вимог, що мають загальнообов' язковий характер, а також ознаки фундаменту форми публічного управління. Саме таке органічне поєднання вищезазначених властивостей свідчить про комплексний характер принципів контролю [6, с. 99]. О.Ф. Андрійко наголошує, що в «літературі існують різні підходи до розуміння принципів контролю та їх систематизації, однак домінуючим є підхід, згідно з яким виділяють загальні засади контролю, що є похідним від принципів управління державою, та спеціальні, пов'язані з особливостями власне контролю» [7, с. 20].

Досліджуючи контроль як правову форму діяльності, В.М. Горшеньов та І.Б. Шахов зазначають, що принцип контролю є основною ідеєю, яка є найвищою концентрацією теорії та практики, своєрідним синтезом роздумів і досвіду [8, с. 73]. На думку O.В. Шоріної, принципи контролю це організаційні та правові основи організації та здійснення контролю, що забезпечують його результативність [9, с. 61]. Д.В. Лученко стверджує, що принципами контролює «науково обгрунтовані й апробовані практикою, закріплені прямо або опосередковано в нормативно-правових актах основи організації та здійснення контролю» [10, с. 200]. Окремі науковці характеризують принципи контролю як основні засади, на яких здійснюються його функції [11, с. 65]. О.П. Гетманець визначає принципи контролю як систему елементів, що становить фундамент методологічної бази контролю [12, с. 88]. В.А. Хмельницький зазначає, що «принцип контролю - це загальноприйняте правило дії в контрольних ситуаціях, він втілює економічні, соціальні та інші закономірності сфери контролю, визначає вимоги, відповідно до яких формує і функціонує підсистема контролю в системі управління виробництвом, суспільством» [13, с. 16-17]. На думку В.К. Колпакова, принципами є позитивні закономірності, пізнані наукою і практикою, закріплені у правових нормах [14, с. 18]. O.I. Миколенко виокремлює такі принципи контролю: загальні принципи права; принципи адміністративного процедурного права (галузеві); принципи, характерні для окремих інститутів чи окремих адміністративних прова- джень (спеціальні) [15, с. 283-284]. Грунтовне визначення запропоноване Т.О. Коломоєць, відповідно до якого принципи контролю - це вихідні, основоположні засади, ідеї, що концентрують у собі досягнення доктрини та практики, виражають соціальні ідеї, виконують функцію загальнонормативного орієнтиру здійснення контрольної діяльності з боку державних органів, громадськості, спрямовані на вдосконалення та забезпечення ефективності такої діяльності [16, с. 41].

В.В. Бурцев аналізує принципи державного фінансового контролю та відзначає як ключову умову досягнення мети і завдань державного фінансового контролю дотримання принципів, тобто основних правил, що охоплюють контрольну діяльність загалом. Науковець наполягає на виділенні основних вимог до організації державного фінансового контролю, які, хоч і не вважає принципами, але наголошує, що саме вимоги зумовлюють ефективне функціонування системи державного фінансового контролю загалом [17]. A.M. Михайловський зазначає, що принципи державного фінансового контролю виступають основоположними керівними положеннями, відповідно до яких будується контрольна діяльність держави [18, с. 89]. Л.А. Савченко вважає принципами фінансового контролю основні засади, на яких базується організація та здійснення фінансового контролю [19, с. 68]. I.М. Ярмак під принципами фінансового контролю розуміє основні вимоги, визначені у нормативно-правових актах, і правила, що не закріплені у праві, але отримали загальне визнання під час організації фінансового контролю та діяльності суб'єктів, наділених контрольними повноваженнями, визначають специфіку організаційної побудови контролюючих суб’єктів, відображають особливості їх діяльності, характеризують професійні якості осіб, що реалізують контрольні функції, забезпечують результативність, ефективність, дієвість фінансового контролю [20, с. 188]. Існує твердження, що принципи фінансового контролю - це основні положення фінансового контролю, що застосовується на практиці [21, с. 16]. Також є таке визначення основних принципів державного фінансового контролю як науково вивірених і підтверджених світовою практикою засад, які є його організаційною і правовою основою [22, с. 94]. Деякі науковці, досліджуючи концептуальні основи організації контролю й аудиту, слушно зауважують, що, на відміну від постулатів, за допомогою яких визначаються межі (рамки) розвитку аудиту, у принципах контролю конкретизуються, удосконалюються його найважливіші характеристики [23, с. 232]. Ю.Р. Баранюк, аналізуючи економічну природу державного фінансового контролю, наголошує, що визначення принципів державного фінансового контролю допоможе забезпечити 
покращення стану управління фінансовими ресурсами держави [24, с. 133].

Таким чином, підсумовуючи вищевикладене, можна запропонувати визначення поняття приниипи державного фінансового контролю - ие теоретично обг рунтовані та норлативно закріплені правові, процесуальні й організаційні основи здійснення публічного фінансового контролю, які визначають його загальну спрялованість, а також керівні засади, на яких грунтується спеиифіка контрольної діяльності органів публічного адліністрування.

Визначивши сутність поняття принципів державного фінансового контролю, видається можливим перейти до вирішення наступного наукового завдання дослідження - з'ясувати конкретний перелік принципів державного фінансового контролю, систематизувати та висвітлити їх сутність, оскільки кожен принцип має як теоретичне, так і практичне значення і дозволяє конкретизувати напрями контрольних відносин. Для цього вважаємо за потрібне проаналізувати думку науковців щодо класифікації принципів контролю у сфері публічних фінансів. Крім того, доцільним вважається розгляд принципів державного фінансового контролю як певної системи, яка є сукупністю взаємопов'язаних і взаємодоповнюючих принципів фінансового контролю у відповідній сфері відносин.

Принципи державного фінансового контролю є конкретизацією характерних особливостей контролю в системі управління, вони грунтуються на його закономірностях і слугують конкретним виразом їхньої дії. Принципи контролю повинні відповідати певним вимогам, до яких відносять: об'єктивність, визначеність, стійкість, конкретність, взаємозв'язок з іншими принципами тощо [25, с. 42]. Варто зазначити, що державний фінансовий контроль, будучи складовим елементом фінансової діяльності держави, зумовлений її особливостями, в т. ч. властивим їй принципами, на яких базується процес контрольної діяльності органів публічного адміністрування, але, звичайно, з адаптацією змісту цих принципів щодо функції контролю.

У науковому оточенні здійснюються окремі спроби щодо формування системи принципів державного фінансового контролю, виділяють різні групи принципів, однак поки відсутній уніфікований підхід до їхнього визначення. В.Ф. Максімова виокремлює низку загальних, загальносистемних, етичних принципів організації та здійснення фінансового контролю. До основних принципів здійснення державного фінансового контролю відносить: законність, обов'язковість, стратегічну спрямованість, неупередженість, всебічність (всеосяжність), системність, плановість, регулярність (своєчасність), конкретність, економічність, глас- ність (за умови дотримання державної, службової, комерційної та іншої таємниці, що охороняється законом), дієвість [26, с. 65-71].

Деякі сучасні науковці виділяють окремо принципи організації та принципи здійснення державного фінансового контролю. Так, на їхню думку, принципами організації державного фінансового контролю є: розмежування місця, ролі, завдань і функцій органів державного фінансового контролю відповідно до законодавства; функціональна, організаційна, персональна й фінансова незалежність органів державного фінансового контролю та їх посадових осіб від підконтрольних об'єктів; координація діяльності органів державного фінансового контролю з метою виключення дублювання у їх роботі та забезпечення єдиної системи державного фінансового контролю на усіх рівнях державної влади. Основними принципами здійснення державного фінансового контролю вважають: законність, обов'язковість, незалежність, об’єктивність, стратегічну спрямованість, неупередженість, гласність (за умови дотримання державної, службової, комерційної та іншої таємниці, що охороняється законом), всебічність (всеосяжність), системність, плановість, регулярність (своєчасність), конкретність, економічність, дієвість [27, с. 19]. Л.А. Савченко стверджує, що принципи фінансового контролю одночасно є принципами його організації та принципами діяльності суб'єктів фінансового контролю, оскільки вони реалізуються під час діяльності останніх, і пропонує власний їх перелік: законність, плановість, публічність, незалежність, об’єктивність, компетентність, оперативність, системність [19, с. 69]. I.К. Дрозд пропонує поділяти принципи державного фінансового контролю на загальні, аналітичні й етичні. Загальні принципи державного фінансового контролю поділяє на принципи: законності, незалежності, об'єктивності, гласності, системності, відповідальності, ендогенності (комунікативності), розподілу контрольних повноважень, компаративності, своєчасності та превентивності [28, с. 48-50]. На думку Н.В. Синюгіної, поділ принципів на окремі групи (загальні, етичні, специфічні) не є доцільним через те, що такий поділ нібито ранжує принципи за їх важливістю, оскільки принципи повинні мати один рівень важливості. Надає власний перелік принципів державного фінансового контролю, який вважає вичерпним: незалежність, законність, системність, систематичність, об'єктивність, публічність [29, с. 111]. В.Ф. Піхоцький поділяє принципи реалізаціїдержавного фінансового контролю за класифікаційними ознаками на такі: методологічні принципи: демократизм, гуманізм, пріоритет прав людини і громадянина, незалежність, законність, об’єктивність, гласність, систематичність, професіоналізм, конфіденційність; 
принципи організації: результативність, адресність, своєчасність, гнучкість, економічність, законність, незалежність, збалансованість, системність і принципи здійснення контролю: законність, об’єктивність, гласність, ефективність, плановість, системність, безперервність, демократичний централізм, відповідальність [30, с. 44-45]. С.В. Бардаш, досліджуючи принципи контролю як поліморфного явища, пропонує класифікаційну модель, в основу побудови якої покладає такі факти: доцільності поділу принципів за видами контролю (зовнішній і внутрішній) на загальні та специфічні, їх обгрунтованості, диференціації (принципи, пов'язані з практичною діяльністю - організацією та здійсненням контролю), а також наголошує на раціональності включення принципів професійної етики суб'єкта контролю до системи принципів. Науковець виділяє п'ятдесят принципів контролю, які систематизовані за групами теоретичних і методологічних принципів [31, с. 7].

C.О. Ніщимна вважає, що принципи публічного фінансового контролю не потрібно класифікувати - їх можна поділити, наприклад, на загальні та внутрішні інституційні. Перша група - загальні принципи публічного фінансового контролю охоплює всі загальні принципи, що застосовуються у фінансовому праві і принципи публічної фінансової діяльності, оскільки контроль здійснюється у межах контрольної діяльності, яка є видом публічної фінансової діяльності. Друга група - внутрішні інституційні принципи публічного контролю. До цієї групи відносить особливі засади, на яких грунтується процес здійснення такого контролю, а також засади організації суб'єктів фінансового контролю; принципи функціонування вищих органів фінансового контролю [32, с. 200].

A.I. Бондаренко, спираючись на положення Лімської декларації керівних принципів контролю як на принциповий документ, який рівною мірою враховує різницю в системах фінансового контролю різних країн, вважає доцільним впровадження всіх принципи фінансового контролю, які в ній закріплено, у діяльність органів державного фінансового контролю в Україні як загальних щодо здійснення контрольних повноважень всіма органами державного фінансового контролю, а специфічні для кожного окремого органу принципи пропонує закріпити в нормативних актах, що визначають їх статус і правові основи діяльності [33]. На погляд В.К. Симоненка, О.І. Барановського, П.С. Петренка, ефективність функціонування системи державного фінансового контролю залежить від умов дотримання таких принципів: достатності, законодавчо визначених повноважень органів державного фінансового контролю; об’єктивності та гласності контрольної діяльності; невідворотності покарань за порушення податково- го та бюджетного законодавства; періодичності контрольних заходів; взаємодії контролюючих органів у формі здійснення спільних перевірок [34, с. 37].

Н.Д. Собкова пропонує запровадження у діяльність контрольних органів державного фінансового контролю таких принципів: узгодженість і плановість дій суб'єктів державного фінансового контролю; об'єктивність і гласність їх діяльності; невідворотність покарання за порушення податкового та бюджетного законодавства; неупередженість та об’єктивність у процесі здійснення державного фінансового контролю; планомірність у системі добору об'єктів фінансового контролю, заснованій на циклічності перевірок; невтручання в оперативну фінансово-господарську діяльність суб'єктів господарювання, за винятком випадків, передбачених законодавством; відкритість і прозорість за винятком необхідності дотримання режиму спеціальних обмежень, у т. ч. нерозголошення комерційної, державної та інших таємниць, відповідно до законодавства; дотримання норм професійної етики; консолідована взаємодія органів загальнодержавного фінансового контролю [35, с. 190].

Підтримуючи і загалом позитивно оцінюючи напрацювання дослідників проблеми визначення принципів державного фінансового контролю, можна зробити висновок, що серед принципів державного фінансового контролю низка таких принципів, як законності, гласності, об’єктивності, незалежності, системності, ефективності повторюється в роботах переважної більшості вчених. Слід зауважити, що вказаний перелік принципів зустрічається також при вивченні основоположних засад будь-якої галузі права або діяльності, насамперед, державної. Отже, можна констатувати, що зазначені основні засади складають загальний перелік приниипів, характерних для будьякої правової діяльності, процесу тощо, зокрема властиві для організації та здійснення державного фінансового контролю.

Інші принципи, які виокремлюються вченими, належать до окремих характеристик організації та здійснення державного фінансового контролю. Так, наприклад, моральні й етичні принципи, компетентність, професіоналізм, відповідальність відносять до принципів діяльності суб'єктів державного фінансового контролю. Водночас принцип гласності вважають синонімом принципу публічності, принцип неупередженості ототожнюють із принципом об’єктивності. Принцип конфіденційності взагалі суперечить принципу публічності, а принцип розподілу контрольних повноважень входить до складу принципу системності. Рівнозначними за змістом можуть бути принципи регулярності, систематичності, періодичності, постійності. Що стосується принципів 
плановості, економічності, оперативності, їх не доцільно закріплювати як принципи державного фінансового контролю, тому що вони не можуть мати місце у всіх без винятку заходах відповідного контролю.

\section{Jimepamypa}

1. Колодій А.М. Принципи права: ґенеза, поняття, класифікація та реалізація. Альланах права. 2012. Вип. № 3. С. 42-46.

2. Юридический этимологический словарь / Р.X. Алеев. Москва : ВИКОН, 2002. 63 с. URL: http://nashaucheba.ru/v32813/.

3. Словник іншомовних слів / за ред. О.С. Мельничука. Київ : Гол. ред. УРЕ, 1974. 776 с.

4. Філософський енциклопедичний словник НАН України, Ін-т філософії ім. Г.С. Сковороди ; ред. B.I. Шинкарук та ін. Київ : Абрис, 2002. 742 с.

5. Демин В.Н. Принцип как форма научного познания. Москва : Юридическая литература, 1976. 354 с.

6. Гаращук В.М. Контроль та нагляд у державному управлінні. Харків : Фоліо, 2002. 176 с.

7. Андрійко О.Ф. Державний контроль в Україні: організаційно-правові засади / О.Ф. Андрійко. Київ : Наукова думка, 2004. 304 с.

8. Горшенев В.М., Шахов И.Б. Контроль как правовая форма деятельности. Москва : Юрид. лит., 1987. $176 \mathrm{c}$.

9. Шорина Е.В. Контроль за деятельностью органов государственного управления в СССР. Москва : Наука, 1981. 300 c.

10. Лученко Д.В. Проблеми систематизації принципів контрольно-процесуальної діяльності. Збірник наукових праць "Державне будівництво та місиеве самоврядування». 2003. Вип. 5. С. 199-207.

11. Білуха М.Т., Микитенко Т.В. Фінансовий контроль: теорія, ревізія, аудит. Київ : Українська академія оригінальних ідей, 2005. 888 с.

12. Гетманець О.П. Правові принципи бюджетного контролю. Форул права. 2017. № 5. С. 84-90.

13. Хмельницкий В.А. Ревизия и аудит. Минск : Книжный Дом, 2005. 48 с.

14. Колпаков В.К., Кузьменко О.В. Адміністративне право України : підручник. Київ : Юрінком Інтер, 2003. 544 c.

15. Миколенко О.І. Теорія адміністративного процедурного права. Харків : Бурун Книга, 2010. 336 с.

16. Коломоєць Т.О., Матвієнко П.Д. Принципи як елемент механізму контролю за діяльністю органів місцевого самоврядування. Адміністративне право прощес. 2012. № 2. С. 31-42.

17. Бурцев В.В. Основные принципы организации государственного финансового контроля в современных условиях. Финансовый менеджлент. 2001. № 2. URL: http://www.finman.ru/articles/2001/2/608. html.

18. Михаловский А.М. Формирование системы принципов государственного финансового контроля на современном этапе. Теория и практика совершенство вания законодательства и правоприленения: традииии и новации: материалы межд. науч. конф., Минск, 30-31 окт. 2009 г. Минск, 2010. С. 89-90.

19. Савченко Л.А. Правові основи фінансового контролю : навчальний посібник. Київ : Юрінком Інтер, 2008. $504 \mathrm{c.}$

20. Ярмак I.M. Поняття принципів фінансового контролю. Європейські перспективи. 2013. № 11. C. $184-191$.
21. Бортник Н.П., Ссімов С.С. Принципи фінансового контролю в системі інвестиційно-правової політики. Вісник Національного університету «Львівська політехніка». Юридичні науки. 2015. № 824. С. 14-20.

22. Микитюк I.C. Принципи організації та здійснення державного фінансового контролю. Вісник Тернопільського державного еконолічного університету. 2006. № 3. C. 88-94.

23. Чая В.Т., Гогия К.А. Концептуальные основы организации контроля и аудита. Аудит и финансовый анализ. 2011. № 4. С. 230-235.

24. Баранюк Ю.Р. Економічна природа державного фінансового контролю. Вісник Хмельницького наиіонального університету. Еконолічні науки. 2017. № 6 (2). C. $127-137$.

25. Лиско Н.А. Основні принципи державного фiнансового контролю в Україні. Актуальні проблеми еконоліки. 2011. № 5 (119). С. 42-47.

26. Максімова В.Ф. Організація державного фінансового контролю : навчальний посібник. Одеса : OHEУ, 2012. $276 \mathrm{c}$.

27. Гуцаленко Л.В., Дерій В.А., Коцупатрий М.М. Державний фінансовий контроль : навчальний посібник. Київ : Центр навчальної літератури, 2009. 424 с.

28. Дрозд I.К., Шевчук В.О. Державний фінансовий контроль : навчальний посібник. Київ : Імекс-ЛТД, 2007. 304 c.

29. Синюгіна Н.В. Теоретичні узагальнення змісту принципів державного фінансового контролю в Україні. Еконоліка: реалї̈ часу. 2013. № 3. С. 106-111.

30. Піхоцький В.Ф. Система державного фінансового контролю в Україні: концептуальні засади теоpiї та практики : дис. ... док. економ. наук : 08.00.08. Львів, 2015. 530 с.

31. Бардаш С.В. Класифікація принципів контролю як складного поліморфного явища. Еконоліка та держава. 2012. № 7. С. 4-8.

32. Ніщимна С.О. Принципи публічної фінансової діяльності в Україні : монографія. Черніигів : ЧДЕУ, $2013.376 \mathrm{c}$.

33. Бондаренко А.I. Принципи здійснення державного фінансового контролю. Державне регулювання проиесів еконолічного і соиіального розвитку. 2011. Вип. № 2 (33). С. 227-233. URL: http://nbuv.gov.ua/ UJRN/Tpdu_2011_2_38

34. Симоненко В.К., Барановський O.I., Петренко П.С. Основи єдиної системи державного фінансового контролю в Україні (макроекономічний аспект). Київ : Знання України, 2006. 280 с.

35. Собкова Н.Д. Принципи державного фінансового контролю. Актуальні проблели функиіонування господарської системи України: XXII-ГА Міжнародна наукова конференція студентів, аспірантів та молодих учених, Львів, 15-16 травня 2015 р. Львів, 2015. С. 189-190.

\section{Анотація}

Прасюк В. М. Принципи державного фінансового контролю: загальна характеристика. - Стаття.

Стаття присвячена загальній характеристиці принципів державного фінансового контролю. Зауважено, що у дослідженні організації та здійсненні державного фінансового контролю принципи слід розглядати як основоположні ідеї, керівні засади, фундаментальні положення, вихідні начала, які є найсуттєвішою основою не лише правових норм, а й усієї правозастосовчої діяльності. Зазначено, що державний фінансовий контроль реалізується за тими самими принципами, що і фінансова діяльність, тому що контроль $є$ ї̈ складовою частиною. Проаналізовано наукові позиції 
у вітчизняних фахових джерелах щодо визначення поняття «принципи державного фінансового контролю» та запропоновано авторське поняття розуміння ïх сутності. 3'ясовано конкретний перелік принципів державного фінансового контролю, систематизовано і висвітлено їх сутність, оскільки кожен принцип має як теоретичне, так і практичне значення і дозволяє конкретизувати напрями контрольних відносин. 3 цією метою проаналізовано думку науковців щодо класифікації принципів контролю у сфері публічних фінансів. Крім того, розглянуто принципи державного фінансового контролю як певну систему, яка є сукупністю взаємопов'язаних і взаємодоповнюючих принципів фінансового контролю у відповідній сфері відносин.

Підтримано загалом напрацювання дослідників щодо проблеми визначення принципів державного фінансового контролю, зроблено висновок, що серед принципів державного фінансового контролю низка таких принципів, як законності, гласності, об'єктивності, незалежності, системності, ефективності повторюється в роботах переважної більшості вчених. Констатовано, що зазначені основні засади складають загальний перелік принципів, характерних для будь-якої правової діяльності, процесу тощо, зокрема властиві для організації та здійснення державного фінансового контролю.

Ключові слова: контроль, державний контроль, державний фінансовий контроль, публічні фінанси, принципи.

\section{Summary}

Prasiuk V. M. Principles of state financial control: general characteristics. - Article.

The article deals with the general characteristics of the principles of public financial control. It is noted that in the study of the organization and implementation of public financial control principles should be considered as fundamental ideas, guidelines, fundamental provisions, starting points, which are the most fundamental basis not only of legal rules, but of all law enforcement activities. It is stated that state financial control is implemented according to the same principles as financial activity, because control is an integral part of it. The scientific positions in the domestic professional sources on the definition of the concept of "principles of state financial control" are analyzed and the author's concept of understanding of their essence is offered. A specific list of principles of state financial control is clarified, their essence is systematized and covered, since each principle has both theoretical and practical importance and allows to specify the directions of control relations. To this end, the views of scholars on the classification of principles of control in public finance have been analyzed. In addition, the principles of public financial control are considered as a certain system, which is a set of interrelated and complementary principles of financial control in the relevant sphere of relations.

The problem of defining the principles of state financial control was generally supported by the researchers, and it was concluded that among the principles of state financial control a number of such principles as: legality, transparency, objectivity, independence, systematicity, efficiency, are repeated in the works of the overwhelming majority of scientists. It is stated that these basic principles form a general list of principles specific to any legal activity, process, etc., including those peculiar to the organization and exercise of public financial control.

Key words: control, state control, state financial control, public finances, principles. 